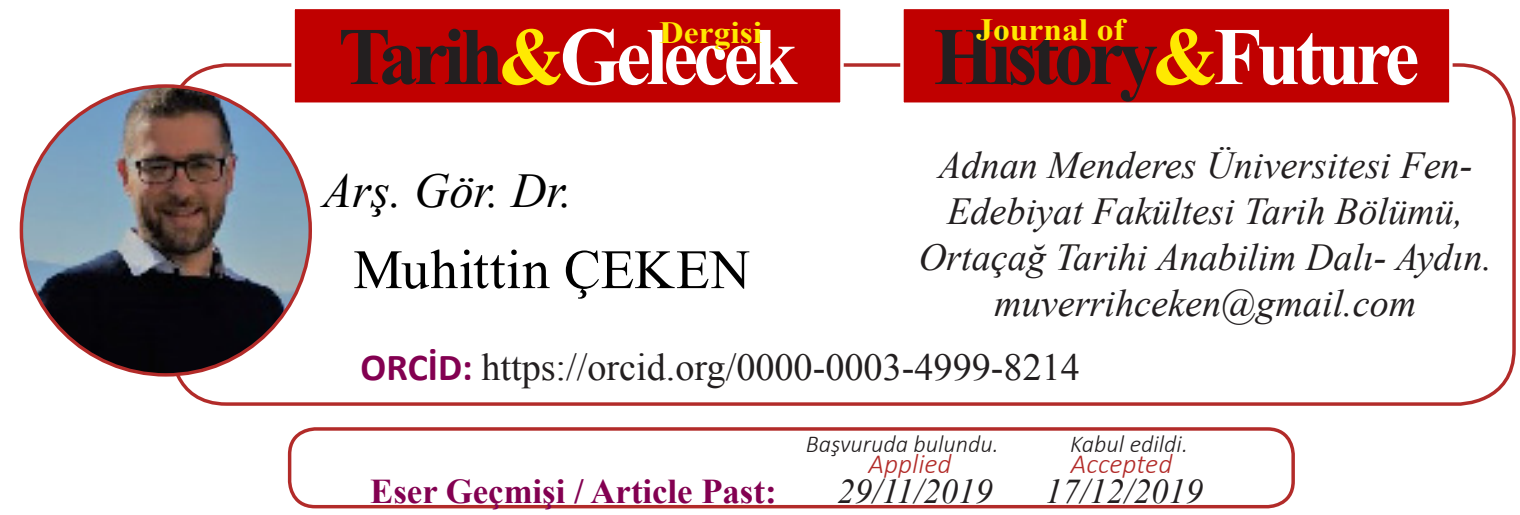

Araştırma Makalesi

DOI: http://dx.doi.org/10.21551/jhf.652947

Research Paper

Orjinal Makale / Orginal Paper

\title{
Tapınak Şövalyeleri’nin Yol Haritası: 1129 Tarihli Tüzük ve Düşündürdükleri
}

\author{
The Knights Templar's Roadmap: The 1129 Statute and its \\ Considerations
}

Öz

Tapınak Şövalyeleri, 1099'da Kudüs'ün Haçlılar tarafindan zaptından sonra, Kudüs'e gelen Hristiyan hacllarl korumak ve bölgenin güvenliğini sağlamak amacıyla 1119/1120 yllında Kudüs'te kuruldu. Dokuz kişilik bir şövalye gurubu tarafindan yoksulluk, itaat ve erdenlik (bekâret) yemini ederek bir sivil toplum kuruluşu hüviyetinde ortaya çıkan örgüt/tarikat, resmi olarak kurulduğu kabul edilen Nablus Konsili'nden, 1129 yılında Papalı tarafindan resmi olarak tanındığı Troyes Konsili’ne kadar, St. Augustin yasalarına bağlı bir yaşam sürdü.

Tapınak Ş̈̈valyeleri, Nablus Konsili'ndeki kuruluşunun ardından, varlığını daha geniş kesimlere duyurmak ve meşruiyetini daha sağlam bir zemine oturtma amacı güden, kurucusu Hugh de Payens 'in girişimleri ve dönemin en etkili din adamlarından biri kabul edilen Aziz Bernard'ın desteğiyle, Troyes Konsili'nde Papalık tarafindan taninan bir örgüt oldu. Tapınak Şövalyelerinin Papalık tarafindan tanınıp resmi bir statü elde etmesi ve Haçlı Seferlerinde etkin role kavuşturulması, böyle bir örgütün işleyişini sağlayacak kurallar silsilesi ihtiyacını meydana getirdi. Tapınak Şövalyelerine resmi bir statü kazandırmak ve Haçl Seferlerindeki fonksiyonunu meşrulaştırmak amacıyla 1129 yllında Fransa'da düzenlenen Troyes Konsili'nde, Tapınak Şövalyelerinin ilk tüzük maddeleri ortaya kondu. Örgütün bundan sonraki süreçte yol haritasını belirleyecek bu tüzükler, ilk olarak Latince ele alınmış, konsilin toplanma tarihinden kısa bir süre sonra ise Fransızcaya çevrilmiştir. Çalışmamızda, Fransızcadan 1992 yılında J. M. Upton-Ward tarafindan İngilizceye çevrilmiş "İlk Tüzük" maddelerini, konuyla alakalı çalışmalar ışı̆̆ında değerlendirerek, bu tüzügün örgütün işleyişsindeki etkilerini yorumlayacağız.

Anahtar Kelimeler: Haçlı Seferleri, Tapınak Şövalyeleri, Troyes Konsili, İlk Tüzük

\section{Abstract}

The Knights of the Temple was founded in Jerusalem in 1119/1120 to protect the Christian pilgrims coming to Jerusalem after the conquest of Jerusalem by the Crusaders in 1099. The Templars, which emerged as a non-governmental organization by taking a vow of poverty, obedience and chastity by a group of nine knights lived a life of St. Augustin laws from the Nablus Council, which officially founded, to the Troyes Council, which was officially recognized by the Papacy in 1129.

After of the Nablus Council, the Knights Templar, with the initiative of its founder Hugh de Payens, who aim to announce its existence to a wider audience and to seat its legitimacy on a more solid ground, and with the support of Saint Bernard, who was considered one of the most influential clergy of the time, became an organization recognized

ATIF: ÇEKEN Muhittin, "Tapınak Şövalyeleri’nin Yol Haritası. 1129 Tarihli Tüzük ve Düşündürdükleri” :

Tarih ve Gelecek Dergisi, 5/3 (Aral1k-2019), s. (670-687)

CITE: ÇEKEN Muhittin, "The Knights Templar's Roadmap: The 1129 Statute and its Considerations" Journal : of History and Future, 5/3 (December- 2019), pp. (670-687) 
by the Papacy. The fact that the Knights Templar was recognized by the Papacy and gained an official status, and that it played an active role in the Crusades, created the need for a sequence of rules to ensure the functioning of such an organization. In order to give the Knights Templar official status and to legitimize their function in the Crusades, the first statutes of the order were introduced the in Troyes Council held in France in 1129. These regulations, which will determine the roadmap of the organization in the future, were first written in Latin and translated into French shortly after the council was convened. In our study, we will evaluate the "First Regulation" articles translated from French into English by J. M. Upton-Ward in 1992 in the light of relevant studies and interpret the effects of this regulation on the functioning of the organization.

Key Words: The Crusades, Knights of Templar, Council of Troyes, Primitive Rule

\section{Giriş}

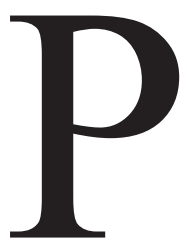

apa II. Urbanus'un 1095 Clermont Konsili'ndeki çağrısının ardından, yaklaşık 20 farklı milletten oluşan büyük bir Haçlı ordusu'', Doğu Akdeniz'e ulaşıp burada krallıklar kurarak bölgedeki mevcudiyetlerini kalıcı hale getirmek adına önemli bir adım attılar. Sırasıyla Urfa, Antakya, Kudüs ve Trablus’ta kurulan bu krallıklar, Haçlıların bölgedeki varlıklarının kurumsal meşruiyetleri açısından önemli bir konum teşkil etti. Genel Haçlı Seferleri içerisinde Haçlıların en önemli; belki de tek başarısı olarak kabul edilen bu krallıkların kurulması kadar varlıklarını sürdürmesi de, Haçlılar için şüphesiz hayati bir önem teşkil etmekteydi. Çünkü bu krallıklar, Haçlıların İslam dünyasına karşı bundan sonra gerçekleştirecekleri mücadelelerin ve bölgede kalıcı hale gelmelerinin merkez noktasını oluşturan en önemli unsurlardı. Bundan dolayı Haçlılar, İslam dünyasının kalbi noktalarında kurdukları bu krallıkları geliştirmek ve güçlendirmek adına önemli adımlar attılar. Bu gelişmelerin en fazla yaşandığı krallık şüphesiz, Haçlı Seferlerinin temel başlangıç noktalarından birini teşkil eden Kudüs Krallı̆̆g'ydı.

Haçlılar, 1099'da Kudüs'te bir krallık kurduktan sonra, hem bölgede kalıcı olmak hem de krallığı güçlendirip geliştirmek amacıyla bir takım uygulamalara yöneldiler. Zira kontluk, demografik nicelik ve askeri güç açısından dönemin zaruri kıldığı ihtiyaçlara cevap vermekten çok uzak görünüyordu. ${ }^{2}$ Çünkü Kudüs Haçlı Krallığı kurulduktan sonra, sefere katılmış olan Hristiyan nüfusun önemli bir kısm1, Avrupa'ya geri dönmek istiyordu ve şehirden kovulan Müslümanlar da henüz Kudüs'ün etrafindan uzaklaştırılamamıştı. Kudüs'te kalmayıp Avrupa'ya dönme konusunda 1srarc1 olan bu Haçlı nüfusu, kontluğun demografik açıdan zayıflamasına sebep oluyordu. Kontluğa yakın bölgelerde bulunan Müslümanlar da, hem krallığın siyasî birliğini tehdit ediyordu hem de Avrupa'dan Kudüs'e haç ibadetini ifa etmek için gelen Hristiyan hacıların güvenliğini tehlikeye sokuyordu. Kudüs Haçlı Kralı Baldwin, bu duruma çözüm üretmek adına çeşitli teşebbüslerde bulunsa da,${ }^{3}$ etrafı Müslümanlarla çevrili krallığın bekası için daha köklü bir çözüm gerekiyordu.

1 G. A. Campbell, The Knights Templars: Their Rise and Fall, River Press, London 1937, s. 86

2 Fulcherius Carnotenses, Kudüs Seferi, Çev: İlcan Bihter Barlas, IQ Kültür Sanat Yayınları, İstanbul 2009, s. 132; Henry Stebbing, The History of Chilvary and the Crusades, Vol. 2, Printed For Constanble and Co., Edinburgh, 1830, s. 15.

3 William of Tyre, A History of Deeds Done Beyond The Sea, Translated and Annotated by Emily Atwater Babcock and A.C. Krey, Volume One, Columbia University Press, New York, 1943, s. 463; James Wasserman, The Templars and the Assasins: The Militia of Heaven, Translated by Lisa Coffin, İnner Traditions, Rochester, Vermont, 2001, s. 158; Steven Runciman, Haçlı Seferleri Tarihi, Cilt: 2, (Çev., Fikret Işıltan), Türk Tarih Kurumu Yayınları, Ankara, 2008, s. 3; Edward Burman, The Templars: Knights of God, Destiny Books, printed and bound in the United States, 1986, s. 13; Relation Des Voyages De Saewulf: A Jerusalem Et En Terre-Sainte, Publiee Pour La Premiere Fois, Paris, 1839, s. 26-27; 
İşte Tapınak Şövalyeleri, bu şartların gerektirdiği bir iklimde kurulmuş ve varlıklarını resmi olarak yaklaşık 200 sene kadar sürdürmüş bir örgüt olarak tarih sahnesine çıkmıştı.

Tapınak Şövalyeleri, dönemin şartlarının gerektirdiği bir iklimde, Kudüs'e gelen hacı adaylarının can ve mal güvenliğini Müslüman saldırılarına karşı koruyup Kutsal Toprakların güvenliğini sağlama ülküsüyle, Hugh de Payens' in ${ }^{4}$ önderliğinde, 9 kişilik bir şövalye grubu tarafından yoksulluk, itaat ve erdenlik (bekâret) yemini ederek (1118-1120) ${ }^{5}$ yllında Kudüs'te kuruldu. ${ }^{6}$ Kudüs Haçlı Kralı II. Baldwin ile Kudüs Patriği Stephan'ın da desteğini alarak kurulan ve dinî-askerî karakteriyle kendi döneminin şahsına münhasır bir örgütü olarak ortaya çıkan Tapınak Şövalyeleri, bu özgün karakteriyle $1128^{7}$ yılında Troyes Konsili'nde Papalık tarafından resmi olarak tanındı. Tabii, kuruluşuna kadar emsali olmayan böyle bir örgütün işleyişini sağlamak için böyle bir örgütün karakteriyle müsemma bir kurallar silsilesine ihtiyacı söz konusuydu. Örgütün dinî-askerî karakterini ortaya koyan ve bundan sonraki süreçte yol haritasını belirleyecek olan anayasa niteliğindeki bu tüzük de Troyes Konsili'nde belirlendi.

\section{Troyes Konsili ve Tapınak Şövalyeleri Örgütü Tüzüğünün Oluşturulması}

Tapınak Şövalyelerinin kuruluşundan dokuz sene sonra, Kudüs Haçlı Kontu II. Baldwin ve Kudüs Patriği Stephen ${ }^{8}$, Tapınak Şövalyeleri örgütüne Papalık tarafından resmi onay almak için bir takım diplomatik faaliyetlerde bulundular. Özellikle Kudüs Kralı II. Baldwin, Kudüs Haçlı Krallı̆̆ kurulduktan kısa bir süre sonra, krallığın nüfusunu oluşturan Avrupalı Hristiyanların Avrupa'ya

Albert of Aachen, Historia Jerosolimitona: History of the Journey to Jerusalem, Edited and Translated by Susan B. Edigington, Clarendon Press, Oxford, 2007. s. xxv; Adrian J. Boas, Archeology of the Military Orders; A survey of the Urban Centers, Rural Settlements and Castles of the Military Orders in the Latin East (C.1120-1291), Routledge Taylor Francis Group, New York, 2006, s. 2; Campbell, s. 14; Muhittin Çeken, Tapınak Şövalyeleri (Kuruluşu, Yükseliş̧i, Kurumsal Yapısı ve Düşüşü), (Basılmamış Doktora Tezi), Manisa, Celal Bayar Üniversitesi Sosyal Bilimler Enstitüsü, Manisa, 2018, s. 10, 17.

4 Hugh de Payens Tapınak Şövalyeleri örgütünün kurucusu ve ilk Üstadı kabul edilmektedir. Hugh de Payesn, I. Haçlı Seferi’ne katılmış Fransız bir şövalye olup katı, anlaşılması güç ve ketun kişiliğe sahip bir insan olarak tasvir edilmektedir. Örgüt kurulduğu zaman 50 yaşlarında olduğu tahmin edilmektedir. Bkz. Wasserman, s. 156.

5 Örgütün kuruluş tarihiyle alakalı dönemin kaynakları birbirlerinden farklı bilgiler sunmaktadır. Surlu William örgütün kuruluş tarihi olarak 1118 yılını işaret ederken, Troyes Konsili’nin tutanaklarını kaleme alan Kâtip Jean Michael de, konsilin toplanış tarihini, Hillary Yortusu'nda, İsa Mesih'in vücut buluşunun 1128., örgütün kuruluşunun dokuzuncu yılı şeklinde ifade eder. Malcolm Barber ise, Örgütün kuruluş tarihi olarak 1120 tarihini vermektedir. William of Tyre, s. 525; The Rule of the Templars: The French Text of the Rule of The Order Knights Templar, Translated and Introduced by J. M. UptonWard, The Boydell Press, Woodbridge, 1992, s. 19-20; s. 26; Malcolm Barber, Yeni Şövalyelik; Tapınak Tarikatının Tarihi, (Çev., Berna Ülner), Kabalcı Yayınevi, İstanbul, 2006, s. 41; bu konuya dair daha ayrıntılı bilgi için ayrıca bkz. Çeken, s. 40-41.

6 William of Tyre, s. 525; The Syriac Chronicle of Michael Rabo (The Great): A Universal History from the Creation, Translation and introduction by Matt: Moosa, Beth Antiach Press, USA, 2014, s. 629; Barber, Yeni Şövalyelik..., s. 26; Boas, s. 2; Burman, The Templars..., s. 18; Thomas Asbridge, Haçll Seferleri, (Çev: Ekin Duru), Say Yayınları, İstanbul 2014, s. 62; Stebbing, s. 27.

7 Bu tarih, Örgüt tüzük maddelerini ihtiva eden Fransızca kaynakta 1128 olarak geçerken, bkz.,La Regle Du Temple, Publiee Pour La Societe De L'histoire De France, Paris, 1886, s. 1; bu kaynağın İngilizceye çevrilmiş versiyonunda Konsilin açılış tarihi olarak 13 Ocak 1129 tarihi geçmektedir. Bkz. The Rule of The Templars:, s. 11; biz de 1128 tarihini, konsilin ilk açılış tarihi, 13 Ocak 1129 tarihini de bu tüzügün kaleme alınış tarihi olarak kabul ediyoruz.

8 Örgütün kuruluş tarihi olarak belirtilen 1119 yılında Kudüs Patriği olarak Warmund of Picquigny’nin ismi geçmektedir. Ancak Troyes Konsili'ne katılan patriğin ismi Stephen olarak geçmektedir. Bkz. William of Tyre, s. 525; Wasserman, s. 156. 
dönme düşüncesinde olmalarından dolayı ciddi bir endişeye kapılmıştı. Çünkü kontluk yeni kurulmuştu ve bölgede varlığını sürdürebilmesi için demografik bir tahkimata ihtiyacı vardı‥ Ancak II. Baldwin, yeni kurulan kontluğu iskân edip gerektiğinde Müslüman tehdidine karşı koruyacak Avrupalı Hristiyan nüfusunun azlığından muzdaripti. ${ }^{10} \mathrm{O}$ dönemde Kudüs Haçlı Krallığının gerek demografik gerekse askeri tahkimatını karşılayacak nüfus yoğunluğundan mahrum olması, II. Baldwin'i Tapınak Şövalyelerinin resmen tanınmasi ${ }^{11}$ ve krallıkta hem askeri hem de demografik ihtiyaçlara bir nebze de olsa cevap vermesi düşüncesine sevk etmişti. Bu sebeple Kudüs Kralı II. Baldwin, o dönemde Papalık üzerinde ciddi bir nüfuz sahibi olan Aziz Bernard'a bir mektup yazarak bu konuda yardımını talep etti. Aziz Bernard'ın olaya müdahil olması Papalık nezdinde karş1lık bulunca, ${ }^{12} 1128$ yılında Fransa'nın Troyes kentinde ${ }^{13}$ bir konsil topland1. ${ }^{14}$

Troyes Konsili, örgütün kuruluşundan dokuz sene sonra, Kral II. Baldwin'in talebi ve Aziz Bernard'ın girişimleriyle Tapınak Şövalyeleri örgütüne resmi bir nitelik kazandırıp, örgütün işleyiş yasalarını ortaya koymak üzere Fransa'da toplandı. Konsilde, örgütün kuruluşundan bu yana takip ettiği St. Augustin kuralları, bu konsille birlikte Aziz Bernard'ın yorumlarıyla farklı bir boyut kazandı. Aziz Bernard, St. Benedict'in etkilediği Cistercians Tarikatı'nın kaidelerini reforme ederek, Tapınak Şövalyelerinin tüzük maddelerini oluşturup kurumsal bir hale getirdi ${ }^{15}$. Bu gelişmeyle birlikte örgüt, ilahi bir kabul elde ederek bundan sonraki işleyişini sürdürecek yol haritası niteliğindeki bir tüzüğe kavuştu. ${ }^{16}$ Zira örgüte yönelik düzenlenen bu tüzük maddelerinden önce Tapınak Şövalyeleri, her ne kadar belli bir işleyişe sahip olsa da, bu durum onların örgüt karakterini yansıtan kriterlerden uzaktı. Troyes Konsili'nde oluşturulan tüzük maddeleriyle birlikte Tapınak Şövalyeleri, ortaya konan hiyerarşik yapı ve disiplin anlayışıyla kendi döneminde tanınır bir örgüt haline geldi ve kendisinden sonraki diğer askeri örgütlere bu anlamda bir emsal teşkil etti. ${ }^{17}$

Aziz Bernard tarafindan oluşturulan Tapınak Şövalyeleri örgüt tüzükleri, Konsile katılan din adamları tarafından müzakere edilerek onayland $1^{18}$ Böylece Tapınak Şövalyelerinin o tarihe kadar takip ettiği uygulamalar, yeni kanun maddeleriyle harmanlanarak örgütün bundan sonraki süreçte takip edecekleri uygulamalar şeklinde ortaya kondu ${ }^{19}$.

9 Wasserman, s. 158.

10 Umberto Eco, Ortaçağ: Katedraller-Şövalyeler-Şehirler, (Çev: Leyla Tonguç Basmacı), Alfa Yayınları, İstanbul 2014, s. 60.

11 The Syriac Chronicle of Michael Rabo (The Great), s. 629.

12 Bernard de Clairvaux, Êloge de la Nouvelle Chevalerie: Vie de Saint Malachie Êpitaphe, Hymene, Lettres, İntroductions, Traductions, Notes et İndex Par, Pierre-Yves Emery, ouvrage Publiê le concours du Centre National Lettres ed de la Delegation Gênêrale â la Langue Française, Paris, 1990, s. 48.

13 Paris'in güneydoğusuna 90 mil mesafede bulunan şehir.

14 Charles G. Addison, The History of Knights Templars: The Temple Church And The Temple, Printed by G. J. Palmer, Savoy Street, London, 1842, s. 16.

15 The Rule of The Templars:, ss. 11-12.

16 Marino Sanudo Torsello, The Book of the Secrets of the Faithfull of the Cross: Liber Secretorum Fidelium Crucis, Translated by Peter Lock, Crusade Text in Translation 21, Routledge Taylor\&Francis Group, Loondon and New York, 2016, s. 283.

17 Tapınak Şövalyeleri’nin Troyes Konsili'yle birlikte oluşturulan tüzük maddeleriyle birlikte dini- askeri karakter olarak tanınıp yeni bir ideoloji olarak tanıtılması ve bu anlamda bir başarı sağlaması, başta Hospitalier Örgütü olmak üzere diğer askeri örgütler açısından bir model teşkil etmiştir. Bkz. Burman, s. $22-23,27$.

18 Charles G. Addison, s. 15.

19 Thomas Fuller, The Historie Of The Holy Warre, Colledge in Cambridge, Cambrdige, 1640, s. 65 
13 Ocak 1129 yılında Fransa'nın Troyes kentinde toplanan konsile farklı bölgelerden, farklı statüye sahip çok sayıda din adamı ve bölge idarecisi katılmıştı ${ }^{20}$. Bölgesel bazda geniş bir coğrafyanın temsiliyle gerçekleştirilen konsil, Aziz Bernard'ın emri üzerine katipliği Jean Michael tarafindan gerçekleştirildi. (Madde 5) ${ }^{21}$ Papa Eugenius'u Alba Piskoposu temsil ediyordu. ${ }^{22}$ Bununla beraber çok sayıda kilise temsilcisi ve örgüt üyelerinin katılımıyla bir anlamda bir tüzük kongresi düzenlenmiştir²3.

Aziz Bernard tarafından düzenlenen ve yukarıda bahsettiğimiz Kilise Babaları ile bölge idarecileri tarafından tasdik edilen konsilde, örgütün dinî-askerî örgüt karakterini ortaya koyan ve ilk sekiz maddesinin ön sözü oluşturduğu 73 bölümden oluşan tüzük maddeleri ortaya konuldu. ${ }^{24}$ $\mathrm{Bu} 73$ maddelik tüzük maddelerinin yarısına yakını St. Benedict' ${ }^{25}$ dayanıyordu. ${ }^{26}$ Bu tüzük maddelerinin temel konularını, örgütün askeri fonksiyonları, örgütsel hiyerarşisi ile örgütün yapısı oluşturmaktayd1. Örgütün tarihsel süreç içerisinde gelişip büyümesine paralel bu tüzük maddeleri de gelişmiş ve $686^{27}$ maddeye kadar ulaşmıştır ${ }^{28}$. Bu da Tapınak Şövalyelerinin zamana ve şartlara uygun davranış biçimleri kazanmaya ve bu bağlamda gelişime ne kadar çok önem verildiğini gösteriyordu.

Örgüt tüzük maddeleri, örgütün süreç içerisindeki gelişimine paralel olarak yaklaşık 150 y1l içerisinde 686 maddeye ulaşmıştır. Bu tüzükler, yazıldıkları dönem ve içeriklerine göre; Primitive Rule (İlk Kurallar), Hierarchical Statutes (Hiyerarşik Kanunlar), Penances (Suçlar), Conventual Life (Manastır Hayatı), Holding of Ordinary Chapters (Olağan Meclis Tutanakları), Further Details on Penances (Suçlar Üzerine Detaylar), Reception into the Order (Örgüte Kabul) şeklinde tasnif edildi. "İlk Tüzük Kuralları (Primitive Rule)" olarak nitelendirilen bu 73 bölümlük tüzük maddeleri, 13 Ocak 1129 tarihinde konsilde müzakere edilerek belirlendi. ${ }^{29}$ İlk olarak Latince (Regula commilitonum Christi) yazılan bu tüzük maddeleri, 1903 yılında Gustav Schnürer tarafından Latince olarak düzenlendi..$^{30}$ Ancak örgüt üyelerinin Latince diline vakıf olmaması ve kendileri için oluşturulan tüzük maddelerini idrak etme konusunda sorun yaşamalarından dolay1 ${ }^{31}, 30$ Mayıs $1135^{32}$ tarihinde de

20 The Rule of The Templars, s. 11.

21 The Rule of The Templars, s. 20; La Regle Du Temple,s. 15.

22 Jacques de Vitry's, History of Jerusalem, Translated From The Original Latin By Aubrey Stewart, Palestine Pilgrims Text Society, London 1896, s. 51.

23 Tam liste için bkz: Çeken, s. 49.

24 Charles G. Addison, s. 15.

25 St. Benedict Kurallarının itaat, tevazu, sessizlik gibi örgütün kuruluş ilkelerini temellendiren olguların yanı sıra, örgütün dini, hukuki ve sosyal yaşantılarını düzenleyen tüzüklere etkileri için bkz. The Rule of St. Benedict, Translated by W. K. Lowther Clarke, London, 1931.

26 Piers Paul Read, Tapınak Şövalyeleri, Dost Kitabevi Yayınları, Ankara, 2003, s. 117.

27 Tapınak Şövalyelerinin 686 maddeden oluşan tüzügü, tarafımızca tamamen Türkçeye çevrilmiş olup kısa süre içerisinde çeviri eser olarak yayımlanması planlanmaktadır.

28 Wasserman, s. 160.

29 The Rule of The Templars, s. 11; Çeken, s. 160.

30 Jochen Burgtorf, The Centrol Convent of Hospitallers and Templers History, Organization and Personnel (1099/1120-1310) Brill Publishing, Baston, 2008, s. 10.

31 Thomas Bailey, Salutare Animas Nostras: The Ideologies Behind the Foundation of the Templars, (Unpublished the Degree of Master Thesis), Northwest Missouri State University Maryville, Missouri, 2012, s. 91.

32 Bazı kaynaklarda, Tapınak Şövalyeleri Tüzüklerinin 1139'da ilk Üstad Hughes de Payens'in halefi Robert de Craon’ün üstadlığı döneminde Fransızcaya çevrildiği belirtilmektedir. Bkz. Wasserman, s. 160 . 
Fransızcaya tercüme edilen tüzük maddeleri ${ }^{33}$, 1886 yılında Henri de Curzon tarafindan Fransızca olarak düzenlendi. ${ }^{34}$ 77-197 arası tüzük maddelerini oluşturan Hiyerarşik Kanunlar (Hierarchical Statutes) ile 224-278 arası tüzük maddelerini kapsayan Suçlar (Penances) kanunların 1165 ile 1187 yılları arasında oluşturulduğu tahmin edilmektedir. ${ }^{35}$ 279-385 arası tüzük maddelerini kapsayan ve örgütün Manastır Hayatı (Conventual Life) hakkında bilgileri ihtiva eden tüzüklerin ise, kesin bir tarih olmamakla birlikte 1187 yılından önceki bir tarihte oluşturulduğu düşünülmektedir. 386-543 arası tüzük maddelerini kapsayan Olağan Meclis Tutanakları (Holding of Ordinary Chapters) 1218 yılından sonraki bir tarihte; 544-656 arası tüzük maddelerini kapsayan Suçlar Üzerine Detaylar (Further Details on Penances) 1257 ile 1268 yılları arasındaki bir tarihte; 657-686 arası tüzük maddelerini kapsayan Örgüte Kabul (Reception into the Order) tüzüklerinin de 1291 yılından önceki bir tarihte oluşturulduğu ifade edilmektedir. ${ }^{36}$ Makalemizin konusunu teşkil eden örgütün tüzük maddeleri konusu, elimizde Fransızca ve Fransızcadan 1992 yılında J. M. Upton-Ward tarafindan İngilizceye tercüme edilmiş versiyonu üzerinden değerlendirilecektir.

\section{Tapınak Şövalyeleri Tüzük Maddeleri}

Tapınak Kanunlarının önsöz niteliğindeki giriş metni, 8 maddeden oluşmaktadır. Bu 8 maddelik önsözün 1. ve 2. maddelerinden ${ }^{37}$, Şövalyelik kurumunun misyonu yeniden tanımlanarak bu duruma dair yeni bir zihin inşasının gerçekleştirilmek istendiği anlaşılmaktadır. Bunu eski şövalyeliğin olumsuz yönlerine yapılan atıflardan ${ }^{38}$, yeni zihin ve düşünce kalıplarının nasıl olması gerektiğine dair tasavvurlardan açıkça anlamaktayız. Bunun yanında yeni hayat nizamı, yeni erdemler, yeni zihin tasarımları, Tapınak Şövalyeliğinin inşasının en temel özelliklerini içerisinde barındırmaktadır. Bu yeni zihinsel atmosferde saf bir kalple hizmet etmek, itaatin erdemlerine varmak ve bunu sürekli hale getirmek aslında nefse karşı koymak anlamına gelmekteydi. ${ }^{39}$ Edward Burman'ın da belirttiği gibi, Tapınak şövalyeliğinin gerçek amac1, şövalyelik kurumunun süreç içerisinde kaybolan değerlerini restore edip özüne dönmesine sağlamak ve ideal bir şövalyelik kurumu ortaya çıkarmaktı..$^{40}$

3. Maddede, konsilin toplanma süreci ile toplanma tarihi hakkında bilgi verilerek yeni şövalyeliğin temellerini atan Üstat Hugh de Payens'in talebiyle farklı bölgelerden konsile katılan üyelerin, Üstat Hugh de Payens' in yeni şövalyeliğin idaresi ve başlangıcı hakkında verdiği malumatların olumlu ve olumsuz yönleriyle değerlendirildiği anlaşılmaktadır ${ }^{41}$. Bu değerlendirme neticesinde Hristiyanlık akideleriyle bağdaşmayan önerilerin reddedildiği, inanca aykırı olmayan önerilerin ise övülüp kabul edildiği belirtilmektedir. ${ }^{42}$

4. Maddede yer alan ifadelerden, konsilde yaşanan gelişmelerin tamamını anlatmak veya ak-

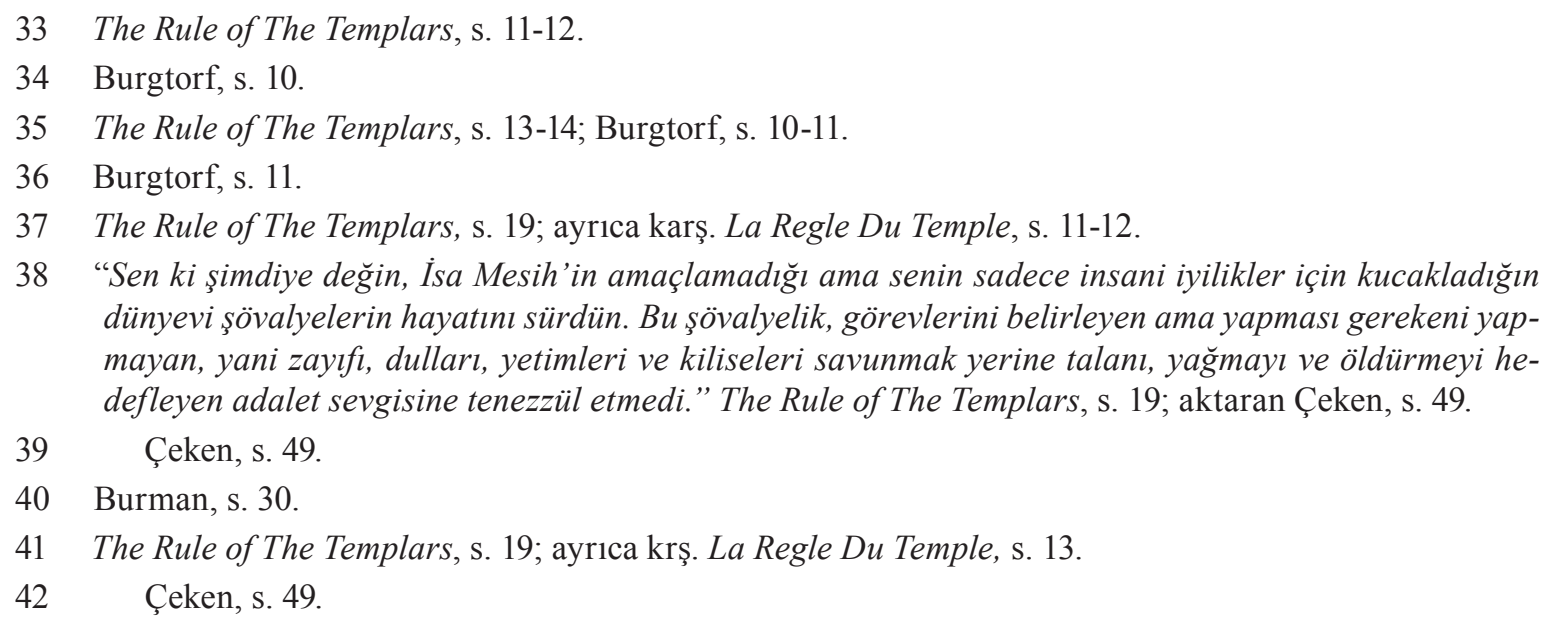
dünyevi şövalyelerin hayatını sürdün. Bu şövalyelik, görevlerini belirleyen ama yapması gerekeni yapmayan, yani zayıfi, dullarl, yetimleri ve kiliseleri savunmak yerine talanı, yağmayı ve öldürmeyi hedefleyen adalet sevgisine tenezzül etmedi." The Rule of The Templars, s. 19; aktaran Çeken, s. 49.

39 Çeken, s. 49.

40 Burman, s. 30.

41 The Rule of The Templars, s. 19; ayrıca krş. La Regle Du Temple, s. 13.

42 Çeken, s. 49. 
tarmanın mümkün olamayacağı, bu gelişmelerin hepsinin hafife alınmayacak kadar önemli olduğu belirtilirken, örgüt üyelerine düşen görevin, Papa II. Honorius ile Kudüs Patriği Stephen'in takdirleriyle alınan bu kararları uygulamanın ve geliştirmenin şeref olarak addedileceği belirtilmiştir ${ }^{43}$. $\mathrm{Bu}$ ibarelerden, Tapınak Şövalyelerinin işleyişine dair gizli ve yoğun bir fikir teatisinin olduğu ve bu kararları uygulamanın Papa ve örgütün kuruluşu ve kurulduğu coğrafyadaki ilişkileri bilen Kudüs Patriği Stephen'in garantörlüğü altında olacağı anlaşılmaktadır.

Yeni şövalyelik anlayışı kriterlerinin çizildiği anlaşılan Tapınak Kanununun önsözü niteliğindeki bu ilk 8 maddeden, Tapınak şövalyeleri örgütünün, bünyesine katacağ1 şövalyelerde sağlam bir irade ve güçlü bir itaat anlayışı ${ }^{44}$ aradığı anlaşılmaktadır. Ayrıca bu yeni şövalyelik anlayışıyla birlikte, eski şövalyelik kurumu inkâr edilerek, önceki şövalyeliğin bu güne kadar İsa'nın öğretilerinin dışında yaşayan, ahlaki ve dini vasıflardan münezzeh cehennemlikler olduğu belirtilmiştir. Yine bu 8 maddelik önsözde Kudüs’ü müdafaa edip korumak ilahi bir görev olarak addedilerek İsa yolunda ölmenin şehitlik mertebesine ulaştıracağı vurgulanmıştır. Ayrıca Papa II. Honorius ve Kudüs Patriği Stephen'in Kutsal Kitapları referans alarak ortak bir kararla örgütün varlığını kabul edip örgütün kuruluş yolunu bu kitapların ilkelerine göre tayin etmeleri, örgütün dini bir meşruiyet zeminine oturtulduğunu da göstermektedir. Tüzük metninin ilk maddesinde: "Illk olarak kendi nefsine gizlice karşı koyan ve kurtarıcı krala bir şövalye olarak, saf bir kalple hizmet etmeyi ve itaatin çok soylu zırhını giymeyi, bunu daimi olarak giymeyi arzulayanlardan bahsedeceğiz.45" cümlesinde yer alan kendi nefsine gizlice karşı koyan ibaresi, laik şövalyelik anlayışına mensup diğer şövalyelerle yaşamış olduğu halde, diğer laik şövalyelerin sahip olmadığı dindarlık ve merhamet duygularını, yaşantısını devam ettirmek için gizlemek zorunda olduğu için onlar gibi davranmak zorunda kalan ve aslında onun yeni şövalyeliğin bir üyesi olmayı hak eden bir şövalye olduğu çıkarımında bulunursak, burada örgütün bugüne kadar laik şövalyeler arasında kendini gizleyerek yaşamış olan şövalyeleri kucakladığı sonucunu da çıkarabiliriz.

Tapınak şövalyeleri örgütünün tüzük kurallarının başladığı 9. ve 10. Maddelerde, ${ }^{46}$ Tapınak Şövalyeleri kardeşlerinin dünyevî beklentilerinden feragat ederek, manevi kurtuluşa ulaşmak adına Kutsal Kitabın kanunlarına uymalarının ve Kutsal Kudüs şehrinin efendilerinin iradelerine mutlak suretle itaat etmelerinin ve de din uğruna savaşmalarının ${ }^{47}$ zaruri olduğu ifade edilmektedir. ${ }^{48}$ Burada hem dini hem de dünyevî otoriteye mutlak itaatin manevi kurtuluş için mutlak suretle gerekli kılındığg anlaşılmaktadır. Bunun yanı sıra, bu dünyanın hilekâr bir dünya olduğu, Tanrının

43 The Rule of The Templars, s. 20; ayrica karş. La Regle Du Temple, s. 15.

44 Tapınak Şövalyeleri örgüt tüzügünün hazırlanmasında, o dönemin önemli tarikatlarının tüzüklerinden etkilenildiği anlaşılmaktadır. Özellikle St. Benedict tarikatının bu konudaki etkisi kaynaklar tarafından vurgulanmakla birlikte, bu etkinin somut göstergelerini ortaya koyan bazı hususlar da söz konusudur. Bunlardan şüphesiz en önemlilerinden birisi de itaat olgusudur. St. Benedict yasalarına göre itaat tevazunun ilk aşaması olup, İsa'nın emrettiği olgular arasındadır. Buna göre İsa'ya itaat eder gibi üstatlara itaat etmek büyük bir önem teşkil etmiştir. Bu itaat duygusunun da cennet beklentisi ve cehennem korkularıyla teşvik edildiği görülmektedir. Bkz. The Rule of Our Most Holy Father St. Benedict, Edited in Latin and English By One of The Benedictine Fathers of St. Michael's, R. Wahsbourne, 18 Paternoster Row, London, 1875, s. 47; Çeken, s. 50.

45 The Rule of The Templars, s. 11; aktaran Çeken, s. 49.

46 The Rule of The Templars, s. 21-22; La Regle Du Temple, s. 21-22; Burman, s. 38.

47 Din uğruna savaş ve bu savaşta ölme halinde şehitlik mertebesine ulaşma durumu ilk olarak, 1095 Clermont Konsili'nde Papa II. Urbanus tarafından Kutsal Topraklar uğruna savaşmaları için Haçlı ordularına vaat edilen bir olguydu. Bu olgu daha sonra, Tapınak Şövalyeleri tarafından da benimsendi. Bkz. Burman, s. 37.

Çeken, s. 210. 
verdiği rızıkla yetinip Tanrı için bu dünyadan yüz çevirerek bedeninin ayartmalarına karşı koyulması ve mütevazı bir yaşam sürülmesi manevi kurtuluşun bir anahtarı olarak takdim edilmektedir. Bütün bunlar gerçekleştirilirken kardeşlerin ibadetlerini asla aksatmamaları önemliydi. Görev için farklı bölgelere gönderilen kardeşler (özellikle Doğuya), kilisede gerçekleşen ibadete iştirak edememeleri durumunda, sabahları kilisede yapılan ibadet yerine on üç defa Babamız duası etmelidirler. Her saat başı için de, yedi defa ve akşamları dokuz defa Babamız duası yapılmalıdır.

Örgüte üye olmak isteyen kardeşlerin görmesi gereken muamele hakkında hükümlerin belirtildiği 11. Maddede, dünyevî şövalyelik tahkir edilerek bu kurumun ebedi cehennem azabına layık bir şövalyelik olduğu belirtilmiştir. Buna göre bu şövalyeliğe mensup bir şövalyenin veya herhangi bir hizmetkârın buradan ayrılıp dünyevî hayatından feragat ederek Tapınak Şövalyeleri örgütüne katılmak istemesi halinde, örgüte hemen kabul edilmemesi gerektiği ifade edilmiştir ${ }^{49}$. Örgüte katılmak isteyen bu şövalye önce örgüte layık olup olmadığı yönünde test edilmelidir. St. Paul'ün de dediği gibi: "Probate spiritus si ex Deo sunt”.yani "Ruhunun Tanrl'dan gelip gelmediğini slnayın." Örgüte dâhil olmak isteyen üyeler konusunda gösterilen hassasiyet, örgütün güvenlik ve liyakat konusunda nasıl tedbirli davrandığını ve bu konuda ne denli seçici olduğunu gözler önüne sermektedir.

Örgüte üyelik konusunda liyakat testinden başarıyla geçip örgüte katılma lütfuna nail olan şövalye veya hizmetkâr, örgütün kuralları ve işleyişi hakkında bilgilendirilmelidir. Eğer aday örgütün kural ve işleyişine itaat etmeyi kabul ederse, Üstadı ve diğer kardeşleri memnun etmeli ve de bunu başarırsa toplanan meclis huzurunda örgüte dâhil edilirdi. Örgütün, bünyesine katılmak isteyen üyelerden işleyişine ayak uydurabilecek ve diğer üyelerle uyumlu, üstada layık olabilecek adayları tercih ettikleri anlaşılmaktadır.

Aforoz edilen şövalyeler hakkında hükümlerin belirtildiği 12 ve 13. Maddelerden 12. maddede, daha önce örgüte katılmamış olup dünyevî şövalyelerin hükmü altındayken aforoz edilmiş bir şövalyenin bir piskopos önünde tövbe edip affedildikten sonra, örgüte dâhil olabileceği ifade edilmiştir ${ }^{50}$. Şövalye, piskopos tarafından affedildikten sonra üstada gönderilir, üstat da şövalyenin örgüte faydalı olabileceğine kanaat getirirse, şövalye örgüte dâhil edilirdi. Örgüte dâhil edilen bu şövalye, örgüt içerisindeki diğer kardeşlerle eşit muameleye tabii tutulurdu. Tapınak şövalyeleri örgütünün aforoz edilmiş bir şövalyeye kapılarını açması, muhtemelen o dönemde örgütün şövalye ihtiyacının fazla olmasıyla alakalı bir durumdur.

13. madden de ise, daha önce örgüte bağlı olup sonradan aforoz edilmiş bir şövalyeye karş1 katı bir tutum sergilendiği anlaşılmaktadır. Buna göre örgüt üyeleri, aforoz edilmiş bir şövalye ile asla konuşamaz, yanında bulunamaz veya herhangi bir eşyasını kullanamazdı. Aforoz edilmiş bir şövalye ile konuşmak, herhangi bir konuyla alakalı onunla temasta bulunmak, bunu gerçekleştiren üyenin de aforoz edilmesine sebepti. Örgüte bağlı üyenin ağır bir suç karşılığı aldığ 1 aforoz cezasına karşı örgütün katı tutumu, muhtemelen diğer üyelerin buna benzer suçlar işlemelerinin önüne geçmeye yönelikti. Ancak aforoz dışındaki cezalara karşı kural esnekti ve ceza almış üye, diğer üyelerle temas kurabilirdi.

Örgüte üye kardeşlerin çocuk sahibi olmasının hoş karşılanmayacağının belirtildiği 14 . Maddede, çocuğunu örgüte vermek isteyen ailelere de, çocuğunu büyütüp eli silah tutacak yaşa getirdikten sonra, İsa Mesih'in düşmanlarına karşı savaşmak için örgüte vermelerinin uygun olaca-

49 The Rule of The Templars, s. 22; ayrica krş. La Regle Du Temple, s. 22-23.

50 The Rule of The Templars, s. 22; La Regle Du Temple, s. 23-25. 
ğ1 belirtilmektedir ${ }^{51}$. Bu durumda, örgütün kuruluş felsefesini oluşturan üç ana unsurdan biri olan erdenlik(bekâret) anlayışından taviz verilmek istenmediği ve örgütün aile kavramına uzak olduğu anlaşılmaktadır.

Tüzügün 15. ve 16. Maddeleri, örgütün ibadet şeklini izah etmektedir. Bu maddelere göre, mezmurların okunması ve duaların yapılmasının oturarak ve duayla Tanrıdan istekte bulunan diğer kardeşlerin dualarının aksamaması için sessizlik içinde yapılması isteniyor ${ }^{52}$. İlahiler ve mezmurlar okunduktan sonra, Kutsal Teslise gösterilen hürmet için ayağa kalkıp sunağa eğilmek gerekmektedir. Bunu yapamayacak kadar zayıf ve hasta olanların sadece başlarını eğmeleri yeterli görülüyor. İncillerin tefsiri okunurken ve te deum laudamus söylendiğinde ve sabah ibadetleri bittiğinde ayakta olunmas1 emrediliyor. ${ }^{53}$

Örgüt üyelerinin giyim-kuşamları hakkında hükümlerin yer aldığı 17-22 arası maddelerde, sınıflarına göre tüm örgüt üyelerinin beyaz ${ }^{54}$, siyah ve kahverengi pelerinler giymesi uygun görülüyor. Özellikle şövalye sınıfını teşkil eden kardeşler, yaz-kış olmak üzere beyaz pelerinler giymek zorunda. Tapınak Şövalyesi üyeleri dışında herhangi bir şövalyenin beyaz pelerin giymesi yasak kabul ediliyor. Beyaz, karanlık yaşamı terk edip aydınlık bir yola baş koymanın ve saflığın, iffetin sembolü olarak görülüyor ve örgüt üyeleri arasında bir iletişim kabul ediliyor ${ }^{55}$. Pacem sectamini cum omnibus et castimoniam sine qua nemo Deum videbit. Yani: 'Tüm barışl getirmek için çabala ve iffetini koru, ki onsuz kimse Tanrı'yı göremez. '56 Yine örgüt giyim-kuşamından bahsedildiği bu maddelerde, örgüt kıyafetlerinin şatafatı çağrıştırıp kibre sevk edecek bezemelerden arınd1rılmış nitelikte ve sade olması gerektiği belirtiliyor. Ayrıca aynı sınıfa mensup üyelerin, giyinip soyunma konusunda pratiklik sağlayacak aynı kıyafetleri giymesini emrediyor. Kibirli ve gururlu bir yaklaşım sergileyerek daha gösterişli elbise isteyen şövalyeye karşı çıkılıp ona daha kötüsünün verilmesi gerektiği belirtiliyor. Yeni elbise alan üyelerin, eskilerini refakatçılara, çavuşlara veya fakirlere vermeleri tavsiye ediliyor. Giyim-kuşam konusunda iklim şartlarının da gözetildiği anlaşılan Tapınak Şövalyeleri örgütünde, Doğudaki iklim şartlarının sıcak olmasından dolayı, Paskalya'dan Azizler Gününe kadar şövalyelerin keten gömlek giymelerine müsaade edilmiştir. Şövalyeler, Üstadın takdirine uygun olarak elbise ve çarşaflara sahip olabiliyordu. Her şövalyenin yatmak için bir yastık, bir battaniye ve bir yatağa sahip olma hakkı vardı. Ayrıca şövalyelerin gömlek, pantolon, ayakkabılarının giyili, kemerlerinin ise takılı olduğu aydınlık bir ortamda uyumaları isteniyor. Bu durum muhtemelen şövalyelerin her an savaşa hazır olmaları gerektiğini vurgulayan bir uygulamadır. Örgüt üyelerinin, sivri burunlu ayakkabı ile bağcıklı ayakkabıları putperestliği çağrıştırdıkları gerekçesiyle giymeleri ise kesinlikle yasaktı.

Tapınak Şövalyelerinin yemek öğünleri ve yemek yeme adabının belirtildiği 23-30 aras1 maddelerde, Örgüt üyelerinin hangi günlerde ne tür g1daları, nasıl bir ortamda tüketecekleri belirtilmiştir. Buna göre, örgüt üyelerinin yemekhane denilen bölümde bir arada olacak şekilde sessizce tam tevazu ve itaatkârlıkla yemeleri gerektiği belirtilmiştir. Akşam yemekleri ve hafif gıdaların tüketildiği ara ögünlerde, İncil okunması ve İncil okunurken de dikkatle ve sessizce dinlenilme-

\footnotetext{
51 The Rule of The Templars, s. 23; ayrica krş. La Regle Du Temple, s. 25-26.

52 The Rule of The Templars, s. 23; La Regle Du Temple, s. 26-27.

53 Çeken, s. 215-216.

54 Beyaz pelerin, Troyes Konsli’nden kısa bir süre sonra, Papa Honorius tarafından örgütün resmi giysisi olarak tanımlandı. Bu muhtemelen örgüte birçok şekil veren Aziz Bernard'ın lideri olduğu Cistercian Tarikatından model alınmıştı. Bkz. William of Tyre, s. 526; Thomas Fuller, s. 65.

55 The Rule of The Templars, s. 24-25; La Regle Du Temple, s. 27-33.

56 The Rule of The Templars, s. 24.
} 
si, Tanrıya olan sevgi ve saygıyla özdeşleştirilmiştir ${ }^{57}$. Yemek yeme ritüelleri, kardeşler arasında çiftler halinde gerçekleşmeliydi. Çünkü beraber yiyen kardeşlerin tasarruf konusunda birbirlerini denetlemeleri amaçlanırdı. Ayrıca her kardeşin kabında eşit yemek, kadehinde eşit miktarda şarap olmasina dikkat edilirdi.

Örgütün yemek öğünlerinde et yemeğine fazla itibar edilmezdi. Yine St. Benedict kurallarından etkilenildiği anlaşılan et yemeyle ilgili tüzükte ${ }^{58}$ Noel, Azizler Günü, Meryem'in göğe yükseldiği gün ve On iki havarinin yortusu hariç, haftada üç defa et yemek yeterli görülüyordu. Örgüt içinde, fazla et yemenin bedeni bozduğuna inanılıyordu. Salı gününe denk gelen oruçtan sonraki gün, çokça et yenmesi uygun görülüyordu. Pazarları da refakatçi ve çavuşların tek ögün, şövalyelerin ise iki öğün et yenmesine müsaade ediliyordu. Salı orucundan sonra çokça, Pazar günlerin ise iki ögün et yenmesine müsaade edilmesi muhtemelen vücudun enerji ihtiyacını karşılamaya yönelik uygulamalard1.

Pazartesi, çarşamba ve cumartesi günleri, iki veya üç öğün sebze veya ekmekle yenilen başka gıda maddeleri tüketilmesi uygun görülmektedir. Hz. İsa'nın Cuma günü acı çektiğine inanılması nedeniyle, örgüt içerisinde bugüne özgü genel bir perhiz uygulaması yapılmaktadır. 1 Kasım'da olan Azizler gününden Paskalya'ya (İsa'nın çarmıha gerildikten sonra 3. günde dirilişi kutlanır ki bu tarih 22 Mart 25 Nisan arasındadır) oruç tutulur.

Akşam yemeklerinin hafif olmasına dikkat edildiği örgütte, tüm kardeşler akşam yemeğinden sonra sessizlik içinde şükretmek için varsa yakınlarda kiliseye gitmeli yoksa eğer bu işlem sarayda gerçekleştirilmeliydi. Yemeklerden arta kalan parçal1, bölünmüş ekmeklerin fakirlere dağıtılması uygun görülürken, bölünmemiş tam parça halinde olan ekmekler ise muhafaza edilirdi. Ekmeklerin onda birinin ise sadaka dağıtıcısına verilmesi gerekmekteydi.

Örgüt üyeleri, gece uyuma vakti geldiğinde Üstadın karar ve hoşgörüne bağlı olarak önce hafif bir yemek yerler ve yemeğin ardından dualarını gerçekleştirirlerdi. Şarap ve yemeklerde ölçülü olmaya dikkat edilmesi istenirdi. Süleyman'ın dediği gibi: Quia vinum facit apostatare sapientes. Şarap akılliyı mahveder.

Sessizliğin korunması hakkında hükümlerin belirtildiği 31. ve 32. Maddelerde, Örgüt üyelerinin, akşam duasını gerçekleştirdikten sonra, acil bir durum olmaksızın birbirleriyle dahi konuşmamaları gerekirdi. Her biri usulca ve sessizlik içinde yatağına girmeli ve acil bir durum varsa bunu refakatçılarına sessizce söylemeleri gerekiyordu. Örgüt içerisindeki diğer üyelerin uykusunu kaçırmamaya yönelik bir tedbir olduğu anlaşılan bu uygulamada, acil çözülmesi gereken bir mesele olması halinde, üstadın izni doğrultusunda yaşça büyük kardeşlerin oluşturduğu meclis bu durumu görüşebilirdi. Örgüt içerisinde "çok laf yalansız olmaz" ve "hayat ile ölüm dilin ucundadır" anlayışı hâkim olup konuşmanın hoş karşılanmayan bir eylem olduğu ve kardeşlerin söylenmemesi gereken şeyleri söylememeleri gerektiği üzerinde durulmuştur ${ }^{59}$. Bu durum muhtemelen örgütün gizliliğe önem vermesi ve örgüte dair herhangi bir bilginin sızdırılması ihtimaline karşı bir önlemdir.

Hasta kardeşler hakkında hükümlerin yer aldığı 33. Maddede, örgüt içinde, hasta kardeşlerin

57 The Rule of The Templars, s. 25-27; La Regle Du Temple, s. 33-38.

58 "to regain their strength, the sick who are very weak may eat meat, but when their health improves, they should all abstain from meat as usual." The Rule of St. Benedict in English, Editor Timothy Fry, The Liturgical Press, Collegeville, Minnesota, 1982, s. 59.

The Rule of The Templars, s. 27; ayrıca krş. La Regle Du Temple, s. 39-40. 
Üstat veya o makamı temsil eden sorumludan izin alarak sabah ibadetlerine katılmayabilecekleri, ancak bunun telafisinin de mutlaka yapılması gerektiği belirtiliyor. Hastalık sebebiyle sabah ibadetlerine katılmayan kardeşler, günde on üç kez rabbin duasını içten ederek telafi edebilirlerdi ${ }^{60}$.

Müşterek hayat ile Üstada dair hükümlerin ifade edildiği 34 ile 35. Maddelerde, müşterek hayat övülerek örgüt üyelerinin böyle bir hayatı benimsemesi gerektiği ve Tanrının herkesin ihtiyacına göre verdiğini, bu nedenle kimsenin kimseden üstün olmadığını, hastalarla ilgilenilmesi gerektiğini ve hafif hastalık geçirenlerin hallerine şükretmeleri gerektiği ifade edilerek, müşterek bir hayatla tüm örgüt üyelerinin barış içinde yaşayabileceği belirtilmiştir ${ }^{61}$. Üstadın mutlak otoritesine vurgu yapılarak, üstadın takdir yetkisi doğrultusunda istediği kardeşe at ve zırh verebileceğini ve üstadın herhangi bir kardeş için uygun gördüğünü bir başka kardeşin kıskanmaması gerektiği belirtilerek kardeşlerden üstada mutlak suretle itaat etmesi isteniyor ${ }^{62}$ ve örgüt içerisinde, kardeşler arasında doğabilecek kıskançlıkların bu şekilde önüne geçilmesi arzulanıyor.

Nasihat verme üzerine hükümlerin değerlendirildiği 36. Maddede, liyakat ilkesinin önemi vurgulanmaktadır. Buna göre, sadece Üstadın vereceği görev veya tavsiyeleri uygulayabilecek kardeşlerin divana çağırılması gerektiği, ancak ortak arazilerin verilmesi ve hanenin işleriyle alakalı meseleler veya örgüte yeni bir üye kazandırılması gibi meselelerde üstadın tavsiyelerini almak için tüm üyeleri toplayabilip görüşlerinin alabileceği belirtilmektedir. Ancak her halükarda son söz üstadındır ${ }^{63}$.

Denizaşırı bölgelere gönderilen kardeşler ve kardeşler arasında barışı korumak üzerine hükümlerin ifade edildiği 37. ve 38. Maddelerde, görev icabı dünyanın çeşitli bölgelerine gönderilen kardeşlerin, örgütün emirlerini uygulamak için güçleri yettiğince gayret göstermeleri gerektiği, söz konusu örgütün çıkarı olduğunda, dışarısı için iyi ve güvenilir bilgiler almak için örgütün kaidelerini bozmadan bazı durumlarda esneyebilecekleri ifade edilmiştir. Böylece her şeyin üstünde iyi işlerin ve bilgeliğin örneğini teşkil edip arkadaşlık kurduklarına ve mekânlarında kaldıklarına onur bağışlansın. Denizaşırı bölgelere gönderilen kardeşlerin kaldıkları mekânlarda düşmanların fiili veya zihinsel saldırılarına karşı koymak için özellikle 1şıkları söndürmemeleri ${ }^{64}$ gerektiği belirtilmiştir $^{65}$. Kardeşler arasında barışı korumanın gerekliliğinin vurgulandığ 38 . Maddede, kardeşlerin birbirini hiddet ve öfke konusunda tahrik etmemeleri, aksine birbirlerini bu hususta kontrol etmeleri gerektiği dile getirilmektedir.

Örgütün kuruluş ilkelerinden birisi olan itaat olgusunun bir kez daha tekrarlandığı 39-44 arası Maddelerde, itaat anlayışı dini bir meşruiyet zeminine oturtularak Tanrının rızasını kazanıp cehennem ateşinden korunmak için İsa Mesih'e itaat eder gibi Üstada itaat etmenin zaruri olduğu belirtilmiştir. İtaat olgusu her şart ve durumda sergilenmelidir. Örgüt üyelerinin üstadın izni olmaksızın Kutsal Mezar Kilisesi ve Kudüs’teki bazı ibadet yerleri hariç başka bir şehir veya kasaba-

\footnotetext{
60 The Rule of The Templars, s. 28; La Regle Du Temple, s. 40-41.

61 The Rule of The Templars, s. 28; La Regle Du Temple, s. 41-42; Burman, s. 32.

62 Çeken, s. 165.

63 The Rule of The Templars, s. 28; La Regle Du Temple, s. 42-43.

64 Bazı kaynaklar, örgüt üyelerinin kıyafetlerini çıkarmadan ve 1şıkları söndürmeden uyumaları gerektiği yönündeki tüzük maddelerinin, eşcinselliği engellemek adına koyulduğunu belirtmektedir: "Sonuçta eşcinsel amours olană̆ Tapınakçılara katılmak için bir neden olmasa da, Troyes Konsili'nin babaları tehlikenin farkındaydılar: Biraderlerin yatakhanesinin gece boyunca aydınlatılması kuralı bu nedenle getirilmişti. Alçak düşman kendilerine günah işleme firsatı vermesin diye. Yatakları, paylaşımları, çıplak ya da karanlıkta uyumaları yasaklanmışt..” Bkz. Read, s. 127.

65 The Rule of The Templars, s. 28-29; La Regle Du Temple, s. 43-44.
} 
ya gitmeleri yasaktır ${ }^{66}$. Örgüt içerisinde komin bir yaşam tarzının gözetildiği anlaşılan bu kriterlere göre, ${ }^{67}$ kardeşler yalnız değil, çiftler halinde dolaşarak birbirlerinin izni olmadan birbirlerinin özeline girmemeli hatta birbirleriyle konuşmamalılar ve hatta Üstadın izni ve bilgisi olmaksızın kendi aralarında eşya takası yapamayıp kilitlenebilir bir çanta veya cüzdan sahibi olamazalar ve üstattan habersiz mektuplaşamazlardı bile. Üstadın bilgisi olmaksızın örgütün herhangi bir üyesi yakınlarının gönderdiği herhangi bir şeyi kabul edemezdi. Dışarıdan gelen herhangi bir eşya veya erzak, ya Üstada veya Erzak Kumandanına takdim edilirdi. ${ }^{68}$ Kısacası örgüt içinde Üstadın haberi olmaksızın hiçbir eylem gerçekleştirilmezdi. Üstat en yüksek mercii olup savaş ve barışa karar verir ve örgüt üyeleri buna uymak zorundadır.

Örgütün hukuki yapısıyla alakalı bilgiler veren 45-47 arası maddelerde, özellikle işlenen suçlara uygulanacak cezalara dair açıklamalar yapılmıştır. 45. Maddeden, hafif suç işıleyen bir üyenin saf bir kalple özür dilemek için suçunu üstada bildirmesi gerektiği ve bu suçu tekrar işlememesi halinde hafif bir kefaretle affedilmesi söz konusuyken, ciddi bir suç işlenmesi durumunda suçu işleyen örgüt üyesi, kardeşlerinin arasından dışlanarak onlarla aynı ortamda yemek yiyip-içmesi yasaklanarak yalnızlığa mahkûm edilip kıyamete kadar kurtarılmak için Üstad ve kardeşlerin yargısına boyun eğmek zorundaydı. İşlenen suç ve günah ne olursa olsun, bunu işleyen zayıf, güçlü, kuvvetli fark etmeksizin kendini savunacak kadar kibirli hale gelen üye cezasız kalmamalıydı. Suçunu telafi edip özür dilemek istemeyen üye, örgütten aforoz edilmeliydi ${ }^{9}$. İnançlı kardeşlerin refakatinden günahkâr koyunu çıkarmak, örgüt için elzemdi. Auferte malum ex vobis. Yani: 'Kötü olanları aranızdan çıkarın.' Suçların karşılığı olarak belirlenen cezalarda, ölçülülük önem teşkil ediyordu. "Ne hoşgörü suçtan daha fazla olsun, ne de günahkârı kötü işlere döndürecek kadar aşırı bir ceza olsun." 70

Örgütün ahlaki yapısıyla alakalı hükümler çizen 48 ve 49. maddelerde, özellikle haset, dedikodu, kin ve iftira gibi ahlaki değerlerde noksanlık yaratan vasıflardan şiddetle uzak durulması gerektiği belirtilmektedir"1 . "Örgüt içerisinde bir kardeş, bir kardeşin günah işlediğini fark ederse, konuyu başka kimseye anlatmadan bu suçu işlediğinden emin olup önce kendisine söylemelidir. Suçu işleyen kardeş bunu kabul etmezse, suça tanık olan kardeş örgüt içerisinden başka bir kardeşe durumu anlatmalı. Suçu işleyen kardeş, suçu bilen iki kardeşin uyarılarını dikkate almazsa da, olay meclise taşınmalı ve suçlu kardeş meclisin önünde suçunu itiraf etmelidir. Diğerlerini kötüleyenler korkunç bir körlükten muzdariptirler ve çoğu büyük bir acı içindedir ki başkalarını imrenmeye karşı kendilerini korumazlar ki bunlar şeytanın kadim kötülüğünün içine atılacaklardı. " Örgüt içerisinde birbirini kontrol mekanizmasının önemli olduğunun hissedildiği bu yargıdan, günümüzde de ahlaki açıdan kusur kabul edilen dedikodu, iftira, haset gibi insani ve toplumsal değerlere zarar veren özelliklerin örgüt içerisinde ciddi bir hassasiyetle yasaklandığı ve örgüt üyeleri arasında ihtilaflara sebebiyet verecek bu özelliklerin şeytanın vesveseleri olarak görüldüğü anlaşılmaktadır.

Örgüt içerisinde konuşmak hoş karşılanmayan bir eylem olarak ifade edilmiştir. Hatta boş konuşmak günah işlemekle eş değer görülmüştür. Kardeşlerin dünyevî meseleleri konuşmaları-

\footnotetext{
66 The Rule of The Templars, s. 29-30; La Regle Du Temple, s. 44-48.

67 Robert T. Wojtowicz, The Original Rule of the Knights Templar: A Translation with Introduction, Unpublished Degree of Master of Art Thesis, Western Michigan University Kalamazoo, Michigan, 1991, s. 12.

68 Çeken, s. 165-166.

69 The Rule of The Templars, s. 30; La Regle Du Temple, s. 49-50.

70 The Rule of The Templars, s. 30; Çeken, s. 221.

71 The Rule of The Templars, s. 31; La Regle Du Temple, s. 51-53.
} 
nın dahi yasak kılındığı örgütte, iyi konuşmak bile gereksiz kabul edilmektedir. Obmutui et silui a bonis. (Biri iyi konuşmaktan bile çekinmeli, sessizliğini korumalıdır.) Hatta kardeşler arasında konuşma eylemini gerçekleştiren bir kardeşin, diğer kardeş tarafından susturulması istenmektedir. "Biz herhangi bir kardeşin ne bir diğerine ne de başka birine, dünyevî hayatta yaptı̆̆ cesurane davranışları anlatmasını yasaklıyor ve kesinlikle men ediyoruz ki bu davranışlar şövalyelikle ilgili görevlerin yapılması sırasında gerçekleştirilen aptallıklar ve etin ahlaksız kadınlarla yaşadığ hazlar olarak adlandırılmalı ve olur ki bunların başka bir kardeş tarafindan anlatıldı̆̆ını duyar, onu derhal susturmalı ve eğer bunu yapamazsa orayı hemen terk etmeli ki kalbini kötü sözden korusun."

Örgüt içerisinde kardeşlik bağı ne kadar güçlü olursa olsun, bazı konularda kardeşler arasında mutlak sınırlar çizilmiştir. Bunlardan birisi de 50. Maddede yer olan hükümdür. Buna göre, kardeşlerden herhangi birisi, bir başka kardeşinden atını veya zırhını isteyemezdi. Eğer böyle bir konuda muhtaciyet durumu varsa, durum üstat veya o makamda üstadı temsil eden kişiye uygun bir şekilde bildirilmelidir ${ }^{72}$.

Örgütün kuruluş felsefesini yansitan ve üzerine yemin edilen üç değerden biri olan yoksulluk ilkesinin tezahür edildiği 51. ve 52. Maddelere göre, Süleyman Tapınağı'nda hüküm süren fakirlikten dolayı, her kardeş en fazla üç ata ve bir refakatçıya sahip olabilir. Refakatçı kendi rızasıyla hizmet etmeyi kabul etmişse, yapacağı hatalardan dolayı dövülmemelidir. Örgüt üyelerinin sahip olduğu dizginlerin nasıl olması gerektiğinin belirtildiği 52. Maddeye göre, kardeşlerin sahip olduğu dizgin ve üzengilerin herhangi bir şekilde süslü olmaması ve sade olması gerektiği belirtilmiştir. Aynı şekilde kardeşlerin sahip olduğu mızrak ve kalkanların da koruyuculardan bağımsız olması gerektiği ifade edilmiştir. Bu durum muhtemelen örgüt üyelerinde kibir duygusunun ortaya çıkmasını önlemeye yönelik bir yaklaşımdır ${ }^{73}$.

Tapınak şövalyeleri üyelerinin en önemli savaş aparatlarından olan mızrak ve kalkanların koruyucuları ile yemek çantası hakkında hükümlerin belirtildiği 53 ve 54 . maddelerde herhangi bir koruyucu olması zararlı görülüp yasaklanmıştır. Örgüt üyelerinin yün ve keten hariç olmak üzere başka bir şeyden yapıllmış yemek çantası kullanmaları yasakt1 ${ }^{74}$.

Avcılıkla ilgili hükümlerin yer aldığı 55 ve 56. Maddelerden, kendini dine adamış ve temel vazifesi Kutsal Toprakları savunmak olan kardeşlerin, ${ }^{75}$ bir zevk ve hobi meşgalesi olan avcılığın peşine düşmesi yasaklanmıştır. Sadece av yapmak yasak olmayıp aynı zamanda av yapan birine kardeşlerden herhangi birinin eşlik etmesi de yasaktır. Av yapmakla geçirilen zaman boş geçirilmiş bir zaman olarak düşünülmekte ve bunun yerine günahların affı için Tanrı'ya dua edilmesi istenmektedir. Avcılığın kesinkes yasaklandığı örgüt içerisinde, aç gözlülüğü temsil ettiği düşünüldüğü için Aslanın avlanmasına müsaade edilmektedir ${ }^{76}$.

Örgütün arazi ve işçiye sahip olması hakkında detayların anlatıldığı 57. Maddede, Tapınak Şövalyeleri örgütünün çıkış kaynağının Kutsal Kitap ve Kutsal Topraklar olduğu belirtilerek, Hristiyanlık düşmanlarını öldürmenin günah sayılmayacağı ve bu örgütün toprak sahibi olup bu toprakları işlemek adına işçi çalıştırabileceğine ve buralarda kendi kanunlarını uygulayabilecekle-

\footnotetext{
72 The Rule of The Templars, s. 31; La Regle Du Temple, s. 53-54.

73 The Rule of The Templars, s. 32; La Regle Du Temple, s. 54-55.

74 The Rule of The Templars, s. 32; La Regle Du Temple, s. 55-56.

75 Çeken, s. 207.

76 The Rule of The Templars, s. 32-33; La Regle Du Temple, s. 56-58.
} 
rine dair hükümler veriliyor ${ }^{77}$. Yani örgütün Hristiyanlık adına yürütülecek dinî bir savaşın temsilcisi olduğu vurgulanarak, mülkiyet hakkının olduğu belirtiliyor.

58. Maddede, kutsal görev için dünyevî zevklerinden feragat eden örgüt üyelerinin kilisenin mülkiyetindeki aşar vergisini toplayan bölge piskoposunun meclis onayını alarak bu vergiyi örgüte verebileceği ifade edilmektedir ${ }^{78}$. Bununla birlikte örgütün aşar vergisiyle birlikte kendisine bir gelir kapısı daha sağladığı söylenebilir.

59. Maddede, Doğu toplumları kavgacı, işkenceci ve Kutsal Kilise ile Onun dostlarına sadık olanlara karşı azap çektirmek isteyen toplumlar olarak betimlenip onlarla hiçbir şekilde alış-veriş yapılmaması ve onlardan gelecek her şeyin sorgulanması gerektiği belirtiliyor ${ }^{79}$. Bu maddede, Doğu toplumları (ki bu toplumlar içerisinde Ortodoks Hristiyanların da olduğu göz önünde bulundurulmalıdır) ötekileştirilerek Katolik Kilisesinin Doğuya karşı geliştirdiği bakış açısı yansıtılmaktadır.

Hasta, yaşlı ve merhum kardeşler hakkında hükümlerin yer aldığı 60-62 arası maddelerde, hasta kardeşlere özen ve dikkatle yaklaşılıp onları ziyaret etmenin erdem olduğu "firmus fui et visitastis me. Yani: 'Ben hastaydım ve sen beni ziyaret ettin'” şeklinde ifade edilerek bu geleneğin sürdürülmesi gerektiği ve hastalara böyle yaklaşmanın cenneti kazandıracağı ifade edilmiştir. Yaşlı kardeşler de, hasta kardeşler gibi özenle ve ihtimamla muamele görüp sağlıklarına kavuşmaları hususunda her türlü fedakârlığın yapılması gerektiği belirtilmiştir. Örgüt içerisinde merhum kardeşe yönelik vefalı yaklaşımlar emredilmiştir. Buna göre, merhum kardeşim ardından yedi gün boyunca günde yüz defa rabbin duası edilip ardından kırk gün boyunca yoksullara et ve şarap verilmesi uygulaması söz konusuydu ${ }^{80}$.

Tapınak Şövalyeleri örgüt karakter ve ideolojisinin yansıtıldığı 63. Maddede, İsa Mesih'in bedenini dindaşları için feda ettiği gibi, örgüt üyelerinin bu uğurda ruhlarıyla mücadele ederek İsa'nın intikamını öldürerek almaları gerektiğini, ancak bu uğurda ölerek Tanrıyı memnun edecekleri vurgulanmıştır. Bu maddeden Tapınak Şövalyelerinin, dini bir motivasyonla, ilahi bir görev üstlenerek Tanrının rızasını kazanacakları ve bunu manevi bir kurtuluş olarak gördükleri anlaşılmaktadir ${ }^{81}$.

Hayır işlerine hizmet eden rahipler ve katipler hakkında hükümlerin belirtildiği 64. Maddede, ortak komisyon, nasıl verilmiş olursa olsun, tüm bağış ve sadakaların papazlara, katiplere ve belirli bir süre hayır işinde çalışanlara verilmesini emretmektedir. Rab Tanrı'nın yetkisine uygun olarak, Kilise'nin hizmetkârları yemek ve giysiye sahip olmak dışında başka hiçbir şeye sahip olup elinde bulunduramazd1. Eğer Üstat uygun görürse, kendilerine bazı taltiflerde bulunulabilirdi ${ }^{82}$.

Dünyevî şövalyeler ve çavuşların taahhüttü hakkında hükümlerin ifade edildiği 65-67. arası maddelerde, merhametle belirli bir süre örgüte hizmet eden şövalyelerden birisi görev esnasında ölürse, ruhuna ithafen yedi gün boyunca bir yoksulun doyurulması ve kardeşlerin otuz defa rabbin duasını etmesi istenmekteydi. İsa Mesih ve Süleyman Tapınağı'na belli bir süre saf bir kalple hizmet eden dünyevî şövalyelere bir at ve silahlar verilirdi. Verilen atın fiyatı önceden belirlenir, hizmet sürecinde yaptığ 1 masraflar örgüt tarafından karşılanırdı. Bu süre zarfında verilen at ölürse, örgüt tarafından karşılanmaya çalışılacaktı ve Üstat yeni bir at verirdi. Hizmet görevi süresi sonun-

\footnotetext{
77 The Rule of The Templars, s. 33; La Regle Du Temple, s. 58-59.

78 The Rule of The Templars, s. 33; La Regle Du Temple, s. 59.

79 The Rule of The Templars, s. 33; La Regle Du Temple, s. 60.

80 The Rule of The Templars, s. 34; La Regle Du Temple, s. 60-63.

81 The Rule of The Templars, s. 34; La Regle Du Temple, s. 63-64.

82 The Rule of The Templars, s. 34-35; La Regle Du Temple, s. 64.
} 
da şövalye kendi ülkesine dönmek isterse, yardım amacıyla atın fiyatının yarısı örgüte bırakılır, diğer yarısı ise örgütün sadakasından karşılanırdı. Tapınağın hanesinde ruhlarının kurtuluşu için ve belli bir süreliğine hayır işi yapmak isteyip farklı bölgelerden gelen refakatçılar ile çavuşlar, örgüt üyelerince desteklenir ve talepleri kabul görürdü̈ ${ }^{83}$. Anlaş1lyyor ki, Tapınak Şövalyeleri örgütü, bu tarihlerde gerek şövalye ve gerekse hizmetçi sınıfı sayısı açısından yetersiz bir durumdaydı ve dışarıdan geçici süreler için gelen bu tür katılımları destekliyordu.

Tüzüğün 68. Maddesinde, örgüt içerisinde dünyevî hayattan kopmayıp, örgüte sözde bağl1 şövalye ve hizmetkârların, örgütün prestijine büyük zarar verdiklerini ve örgüt üyelerinin giydiği saflığı simgeleyen beyaz pelerinleri kullanarak örgüt merkezinden uzak yerlerde örgütün tasvip etmeyeceği hayatı yaşayanların örgüte utanç ve zarar verdikleri belirtilmiştir. Bu şövalye ve hizmetkârların beyaz pelerinler giymeyi hak etmedikleri ve ancak siyah pelerinler onlarda bulunamazsa en ucuz kumaştan yapılmış pelerinler giymeleri tüm meclisin ortak kararı olarak alınmıştır. $\mathrm{Bu}$ maddeden, ilk zamanlarında örgüt içerisinde bir sadakat probleminin yaşandığı, örgüte üye olan bazı kimselerin örgütün kurallarıyla bağdaşmayacak uygulamalar içerisinde oldukları ve uygulamaların da örgütün itibarına gölge düşürecek durumlara sebebiyet verdiği anlaşılmaktadır ${ }^{84}$. Bu durumun da 1129 yılındaki Troyes Konsili'nde dikkate alınarak, örgütün prestijine gölge düşürecek bu tür uygulamaların önüne geçmeyi amaçlayan bir madde koyulduğunu düşündürmektedir. ${ }^{85}$

Evli kardeşler hakkında hükümlerin yer aldığı 69. Maddede, örgüte katılmak isteyen evli adaylarla ilgili kriterler belirlenmiştir. Buna göre, örgüte dâhil edilecek evli kardeşin sahip olduğu mal varlığının bir kısmı, ölümünden sonra örgüte miras olarak bırakılacaktı. Evli üye, eğer örgüte dâhil olduktan sonra herhangi bir varlığa sahip olursa, sahip olduklarının tamamını örgüte bırakacak. Evli kardeş örgüte katıldıktan sonra karısından önce ölürse, örgütün diğer kardeşleri, karısını hayat boyu dışarıdan desteklemek koşuluyla mirasına ortak olabileceklerdi. Bunun yanı sıra evli kardeşler örgüte kabul edildikten sonra, dürüst bir yaşam sürüp diğer kardeşlerle iyi geçinmek zorundayd1 ${ }^{86}$. Tabii bu kardeşin beyaz pelerin giyme hakkı söz konusu değildi. Örgüte katılan üyelerin sahip oldukları mal varlıklarını örgüte bağışlama kriteri, örgütün dışardan aldığı bağışlar dışında, kendi iç dinamikleriyle zenginleşme usulünü de ifade etmektedir denilebilir. ${ }^{87}$

Rahibeler ve kadınlara yönelik örgüt bakış açısının yansıtıldığı 70 ve 71 . Maddelerde, kadınlarla yakınl $1 \mathrm{k}^{88}$ kurulmaması emredilmektedir. Kadınlar kadim kötülük tarafından cennetten saptırılan varlıklar olarak görüldüğü için, onlarla münasebet kurmak, onları Tapınak hanesine rahibeler olarak kabul etmek tehlikeli kabul edilmiştir. Bir kadının statüsü ve yakınlık derecesi ne olursa olsun, kadının yüzüne bakmak, onu öpmekten kaçınılmalıdır. Örgüt üyelerine kadınlardan kesin-

83 The Rule of The Templars, s. 35; La Regle Du Temple, s. 64-66.

84 The Rule of The Templars, s. 35; La Regle Du Temple, s. 67-68.

85 İlgili madde 11 için bkz. The Rule of The Templars, s. 22.

86 The Rule of The Templars, s. 36; La Regle Du Temple, s. 68.

87 Çeken, s. 182.

88 Tapınak şövalyeleri örgütünün kuruluş döneminde model aldığı St. Augustin'e göre bir erkek kadınlardan uzak durmalıdır. St. Augustin, evliliğe karşı olduğunu ve evliliğin sadece cinsel şehvetini dizginlemek için gençliğinde yaptığı bir hata olarak görüyor. Bkz. The Confession of St. Augustine, Translated by j. G. Pilkington, İnternational Collectors Library, New York, 2004, s. 24; Augustinus, İtiraflar, Çev: Dominik Pamir, Kaknüs Yayınları, İstanbul, 1999, s. 132-133.

The Rule of The Templars, s. 36; La Regle Du Temple, s. 69-70; Burman, s. 32. 
likle kaçınmaları emredilmiştir..$^{00}$

Vaftiz babası olmamak üzerine hükümlerin belirlendiği 72. Maddede, örgüt üyelerinin vaftiz edilecek çocukların üzerine vaftiz suyu dökmemeleri ve kesinlikle vaftiz ritüellerinde bulunmayarak hiçbir çocuğun vaftiz babası olmamaları gerektiği belirtilmiştir. ${ }^{91}$

73. maddede, şimdiye kadar bahsedilen tüm tüzüklerin Üstadın takdir yetkisi ve hükmünde olduğu, son karar merciinin Üstat olduğu vurgulanarak, örgüt işleyişinin Üstad tarafindan gözetildiği ve konsilde bu tüzüklere yönelik alınan kararların uygulama ve denetiminin Üstad tarafından gerçekleştirileceği vurgulanmıştır ${ }^{92}$.

73 maddeden oluşan bu tüzüğe ilaveten yazılan 74, 75 ve 76. maddelerde, Tapınak Şövalyeleri için kutsiyet atfeden dini bayram ${ }^{93}$ (yortu) ve ritüeller ile bu bunların kutlanma şekli detaylı bir şekilde izah edilerek bu belirlenen bayram ve ritüeller dişında herhangi bir bayram veya yortuya kutsiyet atfedilmemesi gerektiği açıklanmıştır9

\section{Sonuç}

Tapınak Şövalyelerinin 1129 yılında Fransa'nın Troyes kentinde düzenlenen konsille Papalık tarafından tanınıp Kiliseye bağlı resmi bir örgüt kabul edilmesi, örgüt tarihinin en önemli olaylarından biri olarak kabul edilmektedir. Zira bu olayla birlikte Tapınak Şövalyeleri, Kilisenin İslam dünyasına karşı gerçekleştirdiği Haçlı Seferlerinin asli unsurlarından birine dönüştürülmüş ve varlıkları meşruî bir zemine taşınarak kurumsallaşmaları yönünde önemli bir adım atılmıştı. İşte Troyes Konsili’ye birlikte Tapınak Şövalyelerine kazandırılan “İlk Tüzük Maddeleri” bu adımın

90 Çeken, s. 226.

91 The Rule of The Templars, s. 36; La Regle Du Temple, s. 70; Çeken, s. 215.

92 The Rule of The Templars, s. 37-38; La Regle Du Temple, s. 71-74; Burman, s. 32.

93 Tapınak Şövalyelerinin kutlaması ve gözetmesi gereken dinî bayram ve ritüeller ile bu bayram ve ritüellerin kutlama şekilleri şu şekilde açıklanmıştır:. "Aziz Peter ve Aziz Paul; Aziz Andrew, Aziz James ve Aziz Philip; Aziz Thomas; Aziz Bartholomew; Azizler Simon ve Jude; Aziz James; Aziz Matthew; Aziz Vaftizci John'un Arifesi; Meryem' in Göğe Yükselişi'nin Arifesi ve onun iki gün öncesi, Meryem'in Göğe Yükselişi'nin üç gün öncesi; Hamsin Yortusu'nun arifesi; her mevsimin başılnda tutulan oruçlar; Aziz Laurence'in arifesi; Ağustos ortasindaki Meryem Ana günün arifesi; Tüm Azizler Günü'nün arifesi; İsa Mesih'in Görünmesi'nin arifesi." Ve onlar Pisa'da gerçekleştirilen konsilde Papa Innocent'in buyruklarına uygun olarak yukarda bahsedilen tüm günlerde oruç tutmalılar. Ve eğer yukarda bahsedilen yortu günlerinden herhangi birisi Pazartesi'ye denk gelirse, onu müteakip gelecek olan Cumartesi günü oruç tutmalılar. Eğer Efendimiz'in doğuşu Cuma gününe denk gelirse, kardeşler yortunun onuruna et yemelidirler. Ama Ayin nedeniyle Aziz Mark'in yortusunda oruç tutmalıdırlar; çünkü bu Roma tarafindan insanların ölümlülüğ̈̈ için oluşturulmuştur. Bununla birlikte, eğer Paskalya'nın sekizinci gününe denk düşerse, oruç tutmamalıdırlar. "Efendimiz'in doğuşu; Aziz Stephen yortusu; Aziz Evanjelist John; Kutsal Masumlar; Noel'in sekizinci günü ki bu Yeni Yıl Günü'dür; İsa Mesih'in Görünmesi; Azize Meryem Yortusu; Havari Matyas; Mart'taki Meryem Ana'ya Haber Verilmesi; Paskalya ve onu müteakip üç gün; Aziz George; Azizler Philip ve James, iki havariler; Kutsal Haç'ın bulunuşu; Efendimiz'in Göge Yükselişi; Hamsin Yortusu ve onu müteakip iki gün; Aziz Vaftizci John; Aziz Peter ve Aziz Paul, iki havariler; Azize Mecdelli Meryem, Aziz Havari James, Aziz Laurence, Meryem Ana'nın Göğe Kabulü; Efendimiz'in doğuşu; Gerçek Haç’ın Yüceltilmesi; Aziz Havari Matthew; Aziz Michael; Azizler Simon ve Jude; Tüm Azizler yortusu; kışın olan Aziz Martin günü, kışın olan Aziz Catherine günü; Aziz Andrew; klşın olan Aziz Nicholas günü; Aziz Havari Thomas.” Tapınă̆ın tüm kardeşleri Aziz Martin'in gününden önceki Pazar gününden itibaren Efendimiz'in doğuşuna kadar oruç tutsun, tabii onları engelleyen bir hastalı yoksa. Ve eğer Aziz Martin yortusu Pazar'a denk gelirse, kardeşler onu müteakip gelen Pazar gününü et yemeden geçirmelidir. Aktaran Çeken, s. 218-219.

The Rule of The Templars, s. 37-40. 
en somut vesikaları olmuştur denilebilir.

Troyes Konsili’yle birlikte oluşturulan ve örgütün dinî-askerî karakteriyle müsemma kurallar silsileleri olarak ortaya çıkan 1129 tarihli tüzük, Tapınak Şövalyelerinin erken dönem işleyişini ortaya koyan resmi bir vesika niteliği taşıdığı söylenebilir. Örgütün dini, hukuki, sosyal ve askeri işleyişini yansıtan ve bu açıdan Tapınak Şövalyeleri için bir yol haritası niteliği taşıyan 1129 tarihli tüzük, o dönem için yeni bir ideoloji olarak ortaya çıkan Tapınakçı Şövalyeliğin de, temel doktrinini ortaya koyması açısından kayda değer bir nizamnamedir. Troyes Konsili'nde, uzun bir değerlendirme sonucu müşterek kararlarla alınan ve örgütün dinî-askerî karakterini yansıtması itibariyle de şahsına münhasır bir özelliğe sahip bu tüzük maddelerinin, kapalı bir örgüt yapısını temsil eden, sıkı itaat anlayışına bağlı katı kurallardan oluştuğu anlaşılmaktadır. Tapınak Şövalyelerinin kurumsal çerçevesinin çizildiği bu 73 maddelik tüzük metinleri, örgüt üyeleri için sahip olunması gereken ideoloji, dini hayata dair gözetilmesi gereken ibadet ritüelleri, savaşta ve barışta örgüt disiplinin gerektirdiği emir ve yasaklar başta olmak üzere, işleyişe dair bütün çerçevenin çizildiği bir pusula vazifesi gördüğü anlaşılmaktadır. Tapınak Şövalyelerinin kuruluşlarının erken dönemlerinden itibaren, rehber edindikleri ve örgütün gelişimine bağlı olarak süreç içerisinde mütemadiyen gelişerek 686 maddeye kadar ulaşan bu nizamname, yeni büyümeye başlayan Tapınak Örgütü’nün yol haritası niteliği taşıyarak, ortaçağda emsali olmayan dinî-askerî karakterli yeni bir ideolojinin kurumsallaşmasının ilk resmi vesikasıdır ve yol haritasıdır denilebilir.

\section{Kaynakça}

Addison, Charles G., The History of Knights Templars: The Temple Church And The Temple, Printed by G. J. Palmer, Savoy Street, London 1842.

Albert of Aachen, Historia Jerosolimitona: History of the Journey to Jerusalem, Edited and Translated by Susan B. Edigington, Clarendon Press, Oxford, 2007.

Asbridge, Thomas, Haçlı Seferleri, (Çev: Ekin Duru), Say Yayınları, İstanbul 2014.

Augustinus, İtiraflar, Çev: Dominik Pamir, Kaknüs Yayınları, İstanbul 1999.

Barber, Malcolm, Yeni Şövalyelik; Tapınak Tarikatının Tarihi, (Çev., Berna Ülner), Kabalcı Yayınevi, İstanbul, 2006.

Bernard de Clairvaux, Êloge de la Nouvelle Chevalerie: Vie de Saint Malachie Êpitaphe, Hymene, Lettres, İntroductions, Traductions, Notes et İndex Par, Pierre-Yves Emery, ouvrage Publiê le concours du Centre National Lettres ed de la Delegation Gênêrale â la Langue Française, Paris, 1990.

Boas, Adrian J., Jerusalem In The Time Of The Crusades: Society, Landscape And Art In The Holy City Under Frankish Rule, Published by Routledge, London 2001.

Burgtorf, Jochen, The Centrol Convent of Hospitallers and Templers History, Organization and Personnel (1099/1120-1310) Brill Publishing, Baston, 2008.

Burman, Edward, The Templars: Knights of God, Destiny Books, printed and bound in the United States, 1986.

Campbell, G. A., The Knights Templars: Their Rise and Fall, River Press, London, 1937

Carnotenses, Fulcherius, Kudüs Seferi, Çev: İlcan Bihter Barlas, IQ Kültür Sanat Yayınları, İstanbul 2009. 
Curzon, Henri De, La Regle Du Temple, Publiee Pour La Societe De L'hıstorre De France, Paris 1886.

Çeken, Muhittin, Tapınak Şövalyeleri (Kuruluşu, Yükselişi, Kurumsal Yapısı ve Düşüşü), (Basılmamış Doktora Tezi), Manisa, Celal Bayar Üniversitesi Sosyal Bilimler Enstitüsü, Manisa, 2018

Eco, Umberto, Ortaçăg: Katedraller-Şövalyeler-Şehirler, Çev: Leyla Tonguç Basmacı, Alfa Yayınları, İstanbul 2014.

Fuller, Thomas, The Historie Of The Holy Warre, Colledge in Cambridge, Cambrdige 1640.

Jacques de Vitry's, History of Jerusalem, Translated From The Original Latin By Aubrey Stewart, Palestine Pilgrims Text Society, London 1896.

Read, Piers Paul, Tapınak Şövalyeleri, Dost Kitabevi Yayınları, Ankara, 2003.

Relation Des Voyages De Saewulf: A Jerusalem Et En Terre-Sainte, Publiee Pour La Premiere Fois, Paris, 1839.

Runciman, Steven, Haçlı Seferleri Tarihi, Cilt: 2, (Çev., Fikret Işıltan), Türk Tarih Kurumu Yayınları, Ankara, 2008.

Stebbing, Henry, The History of Chilvary and the Crusades, Vol. 2, Printed For Constanble and Co., Edinburgh, 1830.

The Confession of St. Augustine, Translated by j. G. Pilkington, İnternational Collectors Library, New York, 2004.

The Rule of Our Most Holy Father St. Benedict, Edited in Latin and English By One of The Benedictine Fathers of St. Michael's, R. Wahsbourne, 18 Paternoster Row, London 1875.

The Rule of St. Benedict in English, Editor Timothy Fry, The Liturgical Press, Collegeville, Minnesota, 1982.

The Rule of St. Benedict, Translated by W. K. Lowther Clarke, London 1931.

The Rule of The Templars: The French Text of The Rule of The Order of The Knights Templaer, Translated and İntroduced by J. M. Upton-Ward, Studies in The History of Medieval Religion, V. 6, Boydell Press, USA 1992.

The Syriac Chronicle of Michael Rabo (The Great): A Universal History From The Creation, Translation and İntroduction by Matti Moosa, Beth Antioch Press, USA 2014.

Torsello, Marino Sanudo, The Book of the Secrets of the Faithfull of the Cross: Liber Secretorum Fidelium Crucis, Translated by Peter Lock, Crusade Text in Translation 21, Routledge Taylor\&Francis Group, Loondon and New York, 2016.

Wasserman, James, The Templars And The Assasins: The Milita of Heaven, Translated by Lisa Coffin, İnner Traditions, Rochester, Vermont 2001.

William of Tyre, A History of Deeds Done Beyond The Sea, Translated and Annotated by Emily Atwater Babcock and A.C. Krey, Volume One, Columbia University Press, New York, 1943.

Wojtowicz, Robert T., The Original Rule of the Knights Templar: A Translation with Introduction, Unpublished Degree of Master of Art Thesis, Western Michigan University Kalamazoo, Michigan, 1991. 